\title{
Anti-inflammation effect of hardy kiwifruit (Actinidia arguta) extract in lipopolysaccharide-stimulated macrophages by suppressing NF-kappaB pathway
}

\author{
Dong In Kim ${ }^{1}$, Hyun Jung Kim ${ }^{1,3}$, Ji Hye Lee ${ }^{1}$, So Jung Han ${ }^{1}$, \\ Ha Eun Kim², Kang Soo Park ${ }^{2}$, Hyo Jin Kim², Jeong Hee Nam², \\ Gyeong Yup $\mathrm{Chi}^{1}$, Bong Jeun $\mathrm{An}^{1 *}$ \\ ${ }^{1}$ Department of Cosmeceutical Science, DaeguHanny University, Gyeongsan 38578, Korea \\ ${ }^{2} R \& D$ Team, Leegeehaam Co., Ltd., Seoul 06037, Korea \\ ${ }^{3}$ Institute of Technology, Herbnoori Co., Ltd., Daegu 41581, Korea
}

\section{NF-kappaB 경로의 억제에 의한 lipopolysaccharide로 활성화된 대식세포의 토종다래(Actinidia arguta) 추출물의 항염증 효과}

\begin{abstract}
김동인 ${ }^{1} \cdot$ 김현정 $^{1,3} \cdot$ 이지혜 $^{1} \cdot$ 한소정 $^{1} \cdot$ 김하은 $^{1} \cdot$ 박강수 $^{2} \cdot$ 김효진 $^{2} \cdot$ 남정희 $^{2} \cdot$ 지경엽 $^{1} \cdot$ 안봉전 $^{1 *}$ ${ }^{1}$ 대구한의대학교 화장품약리학과, ${ }^{2}$ (주)이지함 화장품, ${ }^{3}$ 허브누리 기술연구소
\end{abstract}

\begin{abstract}
The aim of this study was to investigate the antioxidant and intracellular anti-inflammatory efficacy of hardy kiwifruit extracted with hot water (HKW), 70\% ethanol (HKE), and 70\% acetone (HKA) in RAW 264.7 macrophages. In order to evaluate the anti-inflammatory effect of hardy kiwifruit extracts, RAW 264.7 macrophages were stimulated with lipopolysaccharide (LPS) to induce the production of inflammation-related factors, which were measured by Westem blotting and real-time PCR methods. i-NOS, COX-2, NF- $\mathrm{kB}$ protein, and mRNA expression showed a concentration-dependent anti-inflammatory effect. The decreases in the mRNA expression levels of interleukin-1 $\beta$ (IL-1ß), interleukin-6 (IL-6), and tumor necrosis factor-a (TNF-a) were concentration-dependent in HKE. Further, the antioxidant effects of hardy kiwifruit on the total polyphenol contents, electron donating ability and ABTS+ radical scavenging activity were evaluated. The total polyphenol contents of HKW, HKE, and HKA were 15.54 \pm 0.29 , $14.41 \pm 0.26$, and $16.82 \pm 0.27 \mathrm{mg} \mathrm{TAE} / \mathrm{g}$, respectively, whereas the electron donating abilities at $1,000 \mathrm{\mu g} / \mathrm{mL}$ of HKW, HKE, and HKA were $30.8,36.1$, and $37.4 \%$, respectively. The ABTS+ radical scavenging activity was fond to be concentration dependent. The nitric oxide (NO) production inhibition activities at $2,000 \mathrm{\mu g} / \mathrm{mL}$ of HKE was $\mathbf{4 2 . 8 \%}$. In conclusion, anti-oxidant and anti-inflammatory test results indicate that hardy kiwifruit can be used as potential anti-inflammatory agents via NF- $\mathrm{kB}$ inhibition.
\end{abstract}

Key words : Actinidia arguta, anti-inflammation, COX-2, inflammatory mediator, NF-kB

\section{서 론}

*Corresponding author. E-mail : anbj@dhu.ac.kr Phone : 82-53-819-1429, Fax : 82-53-819-1429

Received 1 June 2018; Revised 10 July 2018; Accepted 24 July 2018

Copyright (c) The Korean Society of Food Preservation. All rights reserved.
생물체의 대사과정 중 생성되는 활성산소종(reactive oxygen species, ROS)은 고반응성의 free radical로 인한 염 증작용 및 세포노화로 질병을 야기한다 $(1,2)$. 이러한 활성 산소를 제거하는 대표적인 물질로는 $\mathrm{L}$-ascorbic acid (vitamin C), butylated hydroxy anisol(BHA), epigallocatechin gallate(EGCG) 등이 있으며, 이들은 대부분 - $\mathrm{OH}(\mathrm{hydroxyl})$ group으로 활성산소를 소거할 수 있는 환원성 갖으며, 동식 물성 유래 천연 antioxidant로 이루어진다(3). 최근에는 아시 
아를 포함한 중국에서 미세먼지 및 황사에 포함된 내독소 (endotoxin)가 생체 내 활성산소를 발생시키고 염증을 야기 한다고 밝혀졌으며, 내독소는 세균의 세포 내 성분으로서, 그람음성균에서는 세포막에 포함되는 lipopolysaccharide(LPS) 등을 포함한다(4,5). 염증은 물리, 화학적 자극과 미생물의 성분 등이 항원이 되어 나타나는 생물체의 정상적인 면역 반응과 염증이 과도하거나 지속되면 관절염, 천식 및 다발 성 경화증을 포함한 많은 질병의 원인이 된다(6,7). 대식세 포는 생체 내 혈관 및 림프 등에 존재하며 병원균에 대한 즉각적인 방어를 제공함으로써 면역 체계에서 중요한 역할 을 하고, toll-like receptors(TLRs)를 포함한 patternrecognition receptors(PRR)을 통해 병원성 물질을 검출 및 $\mathrm{IL}-1 \beta, \mathrm{IL}-6, \mathrm{TNF}-\mathrm{a}, \mathrm{i}-\mathrm{NOS}, \mathrm{COX}-2$ 와 같은 염증성 인자와 염증을 매개하는 다수의 사이토카인을 방출한다 $(8,9)$. 대식 세포에서 TLR류 중 하나인 toll-like receptor 4(TLR4)는 세 균 막의 당지질인 lipopolysaccharide(LPS)와 같은 항원과 반응하며, NF-kB의 활성화를 가져 오는 IkB kinase(IKK) 복합체를 인산화시킨다. COX-2 및 $\mathrm{iNOS}$ 발현은 전사 인자 $\mathrm{NF}-\mathrm{kB}$ 에 의해 조절되며 자극받지 않은 조건하에서, NF-kB 는 억제인자 IKB- $a$ 에 의해 세포질로부터 정상적으로 분리 되지만, 자극조건하에서는 NF-kB는 핵으로 전위되어 염증 성 사이토카인과 매개체의 발현을 활성화시킨다 $(10,11)$.

토종다래(Actinidia arguta) 열매에 대한 연구는 휘발성 성분(12), 피토케미컬성분(13), 영양성분(14), 아토피 피부 염(15), 경구투여에 대한 안전성(16) 등 연구가 활발히 이루 어지고 있으며, 일부 염증성 사이토카인(17)에 대한 조사가 이루어졌으나, NF-kB 경로에 따른 염증 발생 기전에 대한 연구는 없는 실정이다.

본 연구에서는 토종다래를 water, $70 \%$ ethanol, 및 acetone 으로 추출하여 항산화 효과를 검정하고 염증인자인 iNOS, COX-2과 IL-1 $\beta$, IL-6, TNF-a 사이토카인의 발현을 확인하 였으며, 이러한 인자들의 NF-kB 경로의 연관성을 확인하여 항염증 효과를 알아보고자 하였다.

토종다래의 효능을 확인하여 우리나라 자생토종다래의 기능성 소재로서의 발굴을 위한 자료로 사용될 수 있을 것으로 기대된다.

\section{재료 및 방법}

\section{재료 및 시료추출}

본 실험에 사용된 토종다래(Actinidia arguta)는 강원도 홍천군에서 건조된 상태로 공급받아 사용하였으며, 토종다 래의 추출은 Fig. 1과 같이 추출하였다. Hardy kiwifruit extracted with hot water(HKW)는 물을 시료 중량의 10 배 양을 가하여 $99^{\circ} \mathrm{C}$ 에서 4 시간 동안 3 번 반복하여 추출하였으 며, hardy kiwifruit extracted with $70 \%$ ethanol(HKE) 및 hardy kiwifruit extracted with $70 \%$ acetone(HKA)는 70\% ethanol 및 acetone을 시료 중량에 10 배 양을 가하여 실온에 서 24시간동안 3번 반복하여 추출하였다. 추출물들의 수율 은 $\mathrm{HKW}>\mathrm{HKA}>\mathrm{HKE}$ 순으로 각 $31.8 \%, 26.9 \%, 25.2 \%$ 이였다. 추출물들은 원심분리 및 여과, 농축 후 동결 건조하 여 냉장실에 보관하면서 본 실험의 시료로 사용하였다.

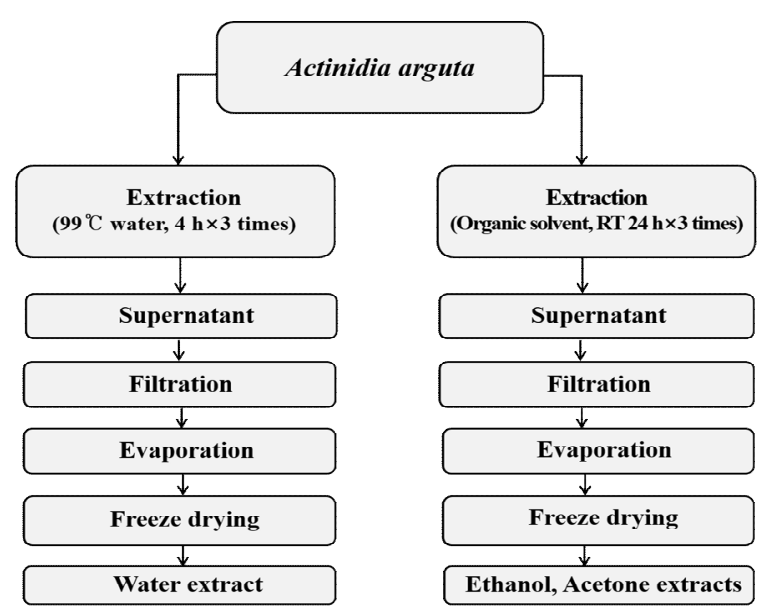

Fig. 1. The procedure for water and organic solvent extraction of hardy kiwifruit (Actinidia arguta).

\section{항산화능 분석 시약}

항산화능 측정 실험에 사용된 시약인 2,2'-azino-bis(3ethylbenzthiazoline-6-sulfonic acid)(ABTS), 1-1-diphenyl2-picryl-hydrazyl(DPPH) 등은 Sigma-Aldrich Co.(St. Louis, $\mathrm{MO}$, USA)에서 구입하였다.

\section{항염증 측정 시약}

항염증 측정 실험에 사용된 시약인 p-dimethylaminobenzaldehyde, sodium nitrite, griess reagent, RIPA lysis and extraction buffer, lipopolysaccharide, protease inhibitor, nuclear and cytoplasmic extraction reagents 등은 Sigma-Aldrich Co.(St. Louis, MO, USA)에서 구입하여 사용하였다. Western blot 을 위한 i-NOS, COX-2, NF-kB 및 secondary antibody는 Santa Cruz Biotechnology(Paso Robles, CA, USA)에서 구입 하였다.

\section{세포 생존율 측정에 사용된 세포주 및 시약}

세포 생존율 측정에 사용된 세포주는 macrophage cell(RAW 264.7)로 American Type Culture Collection (Manassas, VA, USA)에서 구입하여 사용하였다. 세포 배양 을 위한 Dulbecco's modified eagle medium(DMEM), fetal bovine serum(FBS)은 GE Healthcare Life Sciences(Logan, UT, USA)에서 구입하여 사용했으며, $0.25 \%$ trypsin-EDTA, $0.4 \%$ trypan blue stain은 Gibco BRL Co.(Grand Island, NY, USA)에서 구입하여 사용하였고, 3-[4,5-dimethylthiazol- 
2-yl]-2,5-diphenyl-tetrazolium bromid(MTT)는 Sigma-Aldrich Co.에서 구입하여 사용하였다.

\section{실험에 사용된 기기}

본 실험에 사용된 기기는 UV/VIS spectrophotometer (Hitachi, Tokyo, Japan), polarization microscope(Olympus BX 51, Tokyo, Japan), western imaging system(CAS-400SM, Davinch-K, Seoul, Korea), rotary vacuum evaporator(EYELA, Tokyo, Japan), centrifuge(Hitachi), freeze drier(Ilshin, Gimpo, Korea), microscope(Olympus, Tokyo, Japan), $\mathrm{CO}_{2}$ incubator(Hanbaek Scientific Co., Bucheon, Korea), pH meter(Metrohm, Herisau Switzerland), BOD Incubator (Hanbaek Scientific Co.), autoclave(Hanbaek Scientific Co.), ELISA reader(Molecular Devices, San Jose, CA, USA)를 사 용하였다.

\section{총 폴리페놀 화합물 함량 측정}

총 페놀 화합물은 Folin-Denis 방법(18)으로 측정하였으 며, HKW, HKE, HKA, 및 tannic acid를 $10 \mathrm{mg} / \mathrm{mL}$ 농도로 증류수에 희석한 다음 $0.2 \mathrm{~mL}$ Folin-Ciocalteu reagent를 첨 가하여 잘 혼합한 후 3 분간 실온에 방치하였다. 3 분 후 $\mathrm{Na}_{2} \mathrm{CO}_{3}$ 포화용액 $0.4 \mathrm{~mL}$ 를 가하여 혼합하고 증류수를 첨가 하여 $4 \mathrm{~mL}$ 로 만든 후 실온에서 1시간 방치하고, $725 \mathrm{~nm}$ 에서 흡광도를 측정하였다. 이 때 총 폴리페놀 화합물은 tannic acid를 이용한 표준곡선으로부터 양을 환산하였다.

\section{전자공여능 확인}

전자공여능(electron donating ability, EDA)은 Blois(19)의 방법을 변형하여 측정하였다. HKW, HKE, HKA, 및 EGCG, $\mathrm{BHA}$ 는 $70 \%$ ethanol에 희석하여 사용하였다. 각 시료용액 과 $0.2 \mathrm{mM}$ 의 $\mathrm{DPPH}$ 를 $1: 1$ 비율로 넣고 교반한 후 흡광도 $517 \mathrm{~nm}$ 에서 측정하였다. 전자공여능은 시료용액의 첨가군 과 무첨가군의 흡광도 감소율로 나타내었다.

$$
\text { 전자공여능 }(\%)=\left(1-\frac{\text { 시료첨가군의 흡광도 }}{\text { 무첨가군의 흡광도 }}\right) \times 100
$$

\section{ABTS cation radical scavenging activity 확인}

$\mathrm{ABTS}^{+}$radical을 이용한 항산화력 측정은 $\mathrm{ABTS}^{+}$radical decolorization assay 방법(20)에 의하여 측정하였다. $\mathrm{HKW}$, HKE, HKA, 및 EGCG, BHA는 증류수에 희석하여 사용하 였다. $7 \mathrm{mM}$ ABTS와 $2.4 \mathrm{mM}$ potassium persulfate를 혼합하 여 실온에서 24시간 동안 방치하여 $\mathrm{ABTS}^{+}$radical을 형성 시킨 후 ethanol로 희석하여 $\mathrm{ABTS}+\frac{8}{8}$ 액 $100 \mu \mathrm{L}$ 에 시료 $100 \mu \mathrm{L}$ 를 더하여 1 분 동안 방치한 후 흡광도 $734 \mathrm{~nm}$ 에서 측정하였다.

$$
\text { 소거율 }(\%)=\left(1-\frac{\text { 시료첨가군의 흡광도 }}{\text { 무첨가군의 흡광도 }}\right) \times 100
$$

세포 배양

Mouse 유래 대식세포인 RAW 264.7은 한국 세포주 은행 (KCLB)에서 구입하였고 $10 \%$ Fetal bovine serum(FBS)와 $1 \%$ penicillin-streptomycin이 첨가된 DMEM 배지를 사용 하였다. 세포는 $37^{\circ} \mathrm{C}$ 및 $5 \% \mathrm{CO}_{2}$ 에서 배양하였다.

\section{MTT assay에 의한 세포 생존율 확인}

세포 생존율 측정은 Carmichael(21)의 방법에 따라 수행 하였다. 먼저, RAW 264.7 대식세포를 96-well plate에 $5 \times 10^{4}$ cells/well이 되도록 $180 \mu \mathrm{L}$ 분주하고, 시료를 농도별로 조제 (sol. DMEM)하여 $0.02 \mathrm{~mL}$ 첨가한 후 $37^{\circ} \mathrm{C}, 5 \% \mathrm{CO}_{2}$ incubator에서 24 시간 배양하였다. 여기에 $5 \mathrm{mg} / \mathrm{mL}$ 농도로 제조한 MTT 용액 $0.02 \mathrm{~mL}$ 첨가하여 4시간 배양한 후 배양 액을 제거하고 각 well당 $0.15 \mathrm{~mL}$ 의 DMSO를 가하여 실온 에서 30분간 반응 시킨 뒤 ELISA reader로 $540 \mathrm{~nm}$ 에서 흡광도를 측정하였다. 세포 생존율 측정은 시료용액의 첨 가군와 무첨가군의 흡광도 감소율로 나타내었다.

$$
\text { 세포 생존율 }(\%)=\frac{\text { 시료첨가군의 흡광도 }}{\text { 무첨가군의 흡광도 }} \times 100
$$

\section{Nitric oxide 측정}

Nitric oxide(NO) 측정은 세포배양액에서 $\mathrm{NO}$ 의 양을 nitrite and nitrate로서 측정 하였다(22). Nitrate에 대한 nitrate 로 환원된 후의 안전한 형태인 griess reagent(Sigma)를 사용 하였으며, 6-well plate에 $5 \times 10^{5}$ cell/well을 $10 \% \mathrm{FBS}$ 가 포함 된 배지를 사용하여 24시간 배양시킨 다음 DMEM 배지를 용매로 농도별로 희석한 시료(HKW, HKE, HKA)를 1시간 동안 첨가한 후, LPS $1 \mathrm{\mu g} / \mathrm{mL}$ 이 되도록 normal군을 제외한 모든 well에 24시간 동안 자극시켰다. 세포 배양액을 모아 griess reagent로 10 분간 반응시킨 후에 $540 \mathrm{~nm}$ 에서 흡광도 를 측정하였다.

\section{Western blot}

i-NOS, COX-2 단백질 발현양을 확인하기 위해, RAW 264.7 대식세포를 DMEM 배지를 사용하여 $5 \times 10^{5}$ cells/well 만큼 6-well plate에 접종하고 5\% $\mathrm{CO}_{2}$ incubator에서 24시간 동안 배양한 후, 세포에 DMEM 배지로 희석한 $\mathrm{HKW}$ 및 $\mathrm{HKE}, \mathrm{HKA}$ 를 $100,500,1,000,2,000$ 또는 100, 500, 1,000 $\mu \mathrm{g} / \mathrm{mL}$ 로 1 시간 동안 처리한 후, i-NOS, COX-2의 경우는 $1 \mathrm{\mu g} / \mathrm{mL}$ 의 LPS를 첨가하여 24시간 동안 자극시켰으며, NF$\kappa \mathrm{B}, \mathrm{p}$-IKB 단백질 발현양 확인을 위해서는 세포를 $1 \times 10^{6}$ cells/well만큼 $100 \mathrm{~mm}$ dish에 접종하고 24시간 동안 배양 한 후, DMEM 배지로 희석한 $\mathrm{HKE}$ 를 $2,000 \mu \mathrm{g} / \mathrm{mL}$ 로 1 
시간 동안 처리한 후, $1 \mathrm{\mu g} / \mathrm{mL}$ 의 LPS를 첨가하여 1 시간 동안 자극시켰다. 배지를 제거하고 phosphate buffered saline(PBS)로 2회 세척하고, I-NOS, COX-2의 단백질의 발 현양 확인의 경우는 RIPA buffer로 추출한 후, 원심 분리 과정을 거쳐 pellet을 제거하였으며, NF-kB, p-IkB의 단백질 발현양 확인의 경우는 nuclear and cytoplasmic extraction reagents를 활용하여 세포의 핵과 단백질을 분리하였다. 그 이후, Brad-ford 분석법으로 단백질을 정량하고, BSA 대비 $10 \mathrm{\mu g} / \mathrm{mL}$ 의 단백질을 $10 \%$ SDS-PAGE에서 전기영동하여 분리하였다. 분리된 단백질은 PVDF membrane에 옮긴 다 음 실온에서 membrane을 5\% skim milk(sol. TBST)로 2시간 동안 blocking 한 다음 10 분마다 tris buffered saline with tween 20(TBST)로 3회 세척하였다. 1차 항체는 1:1,000으로 희석하여 실온에서 2시간 동안 incubation 시켰다. 그 후, TBST로 10 분간 3회 세척 한 후 membrane을 horseradish peroxidase(HRP)가 포함된 각각의 2차 항체를 1:1,000으로 희석하여 1 시간 동안 반응시켰다. 10 분마다 TBST로 3 회 세척하였다. Davinch Western ${ }^{\mathrm{TM}}$ imaging system(Seoul, Korea)을 이용하여 protein 발현량을 측정 하였다.

\section{cDNA 합성}

$100 \mathrm{~mm}$ dish에 $1 \times 10^{6}$ cells/well만큼 접종을 하고 24시간 동안 배양한 후 DMEM 배지로 희석한 시료(HKW, HKE, $\mathrm{HKA}$ )를 1 시간 동안 $37^{\circ} \mathrm{C}, 5 \% \mathrm{CO}_{2}$ incubator에서 배양 한 후, $1 \mathrm{\mu g} / \mathrm{mL}$ 의 LPS를 첨가하여 24시간 자극시켰다. 상등액 을 제거한 후 Trizol lysis buffer를 각각의 dish 에 $1 \mathrm{~mL}$ 씩 분주하여 세포를 lysis한 후 상온에서 5 분 동안 방치하였다. Trizol buffer를 lysate에 $1 \mathrm{~mL}$ 당 chloroform 0.2-0.5 mL를 첨가하여 약 15 초 동안 강하게 vortexing 해주고 다시 상온 에서 5 분간 방치하였다. 원심분리기를 이용하여 $4^{\circ} \mathrm{C}$ 에서 $12,000-15,000 \mathrm{rpm}$ 으로 15 분간 실시하고 상등액 $0.4 \mathrm{~mL}$ 를 새 tube로 옮겨서 isopropyl alcohol $400 \mu \mathrm{L}$ 와 1:1로 조심스럽 게 섞어준 뒤 상온에서 5-10분간 두었다. 앞의 과정과 동일 하게 원심분리를 하고 tube의 바닥에 있는 RNA pellet을 확인한 후 상층액을 제거하였다. $70 \%$ ethanol로 RNA pellet 을 washing 해주고 남은 ethanol을 날린 후 RNase free water 에 RNA pellet을 녹여주었다. cDNA로의 역전사와 증폭은 TOPscript $^{\mathrm{TM}}$ RT DryMIX(Enzynomics, Daejeon, Korea)를 이용하여 시행하였다.

\section{Real-time PCR}

SYBR Green PCR Master Mix(Applied Biosystems, Foster City, CA, USA)를 사용하여 cDNA와 $\mathrm{TOPreal}^{\mathrm{TM}} \mathrm{qPCR} 2 \mathrm{X}$ PreMIX(Enzynomics), primer(Table 1)를 넣고 ABI step one plus(Applied biosystem, Foster City, CA, USA) 기기를 이용 하여 실시간 정량 분석을 하고 StepOne Software(Applied Biosystems)를 사용하여 $95^{\circ} \mathrm{C}$ 에서 2 분간 denature시킨 후 $95^{\circ} \mathrm{C}$ 에서 10 초, $60^{\circ} \mathrm{C}$ 에서 15 초, $72^{\circ} \mathrm{C}$ 에서 20 초간 반응하는 온도순환조건을 40 회 반복한 결과를 분석하였다.

Table 1. Sequences of PCR primers used for quantitative real-time PCR

\begin{tabular}{ccc}
\hline Gen & Primer & Sequence \\
\hline \multirow{2}{*}{ i-NOS } & Sense & $5^{\prime}$-ACATCGACCCGTCCACAGTAT-3' \\
& Antisense & $5^{\prime}$-CAGAGGGGTAGGCTTGTCTC-3' \\
COX-2 & Sense & $5^{\prime}$-TCCCTAAAGGAAAAGTGGGACC-3' \\
& Antisense & $5^{\prime}$-GAGCGCATTAACCTCAGGACC-3' \\
IL-1ß & Sense & $5^{\prime}$-GCACTACAGGCTCCGAGATGAA - 3' \\
& Antisense & $5^{\prime}$-GTGGTTGCTTGGTTCTCCTTGT - 3' \\
IL-6 & Sense & $5^{\prime}$-CTTGGGACTGATGCTGGTGACA-3' \\
& Antisense & $5^{\prime}$-GCCTCCGACTTGTGAAGTGGTA-3' \\
TNF-a & Sense & $5^{\prime}$-CCGCTCGTTGCCAATAGTGATG-3' \\
& Antisense & $5^{\prime}$-CATGCCGTTGGCCAGGAGGG-3' \\
GAPDH & Sense & $5^{\prime}$-TGACCACAGTCCATGCCATC-3' \\
& Antisense & $5^{\prime}$-GACGGACACATTGGGGGTAG-3' \\
\hline
\end{tabular}

\section{통계처리}

모든 실험은 3 회 반복하여 측정하였고, 그 결과는 평균값 \pm 표준편차로 나타냈으며 통계적 분석은 SPSS 프로그램을 이용하여 각 처리구간의 유의성 $\left({ }^{*} \mathrm{p}<0.05,{ }^{* *} \mathrm{p}<0.01\right)$ 검증을 위해 분산분석(analysis of variance, ANOVA) 후 Turkey test 로 다중비교를 실시하였다.

\section{결과 및 고찰}

\section{총 폴리페놀 화합물 함량}

Hydroxyl기를 갖는 phenol성 화합물은 단백질 및 고분자 들과 결합하여 전자 환원에 의하여 항산화, 항암, 항염증 등을 다양한 생리활성을 나타내는 것으로 알려져 있으며

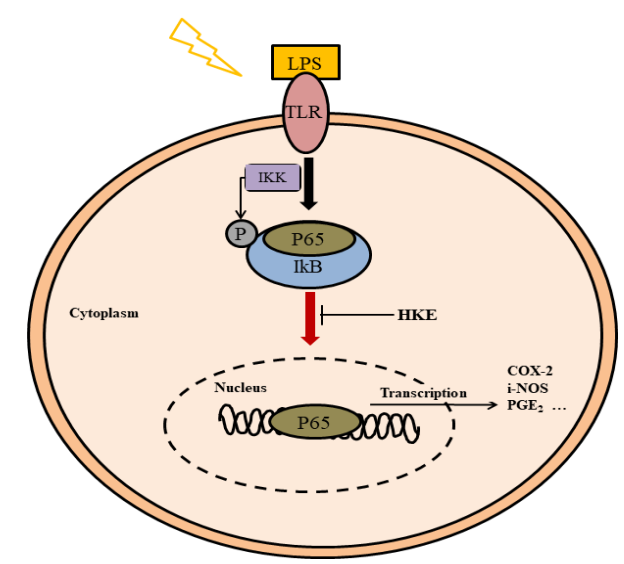

Fig. 2. Anti-inflammatory mechanism of hardy kiwifruit (Actinidia arguta) through inhibition of NF- $\mathrm{kB}$. 
Table 2. Polyphenol contents of hardy kiwifruit (Actinidia arguta)

\begin{tabular}{cc}
\hline Solvent type of extract & Polyphenol contents $(\mathrm{mg} \mathrm{TAE} / \mathrm{g})^{1)}$ \\
\hline Water extract & $15.54 \pm 0.29^{23)}$ \\
$70 \%$ Ethanol extract & $14.41 \pm 0.26$ \\
$70 \%$ Acetone extract & $16.82 \pm 0.27$ \\
\hline
\end{tabular}

${ }^{1)}$ TAE standards for tannic acid equivalents.

${ }^{2)}$ All value are expressed as Mean \pm SD of triplicate determinations.

${ }^{3)}$ Different superscripts within the column are significantly different at $\mathrm{p}<0.05$ by Duncan's multiple range test.

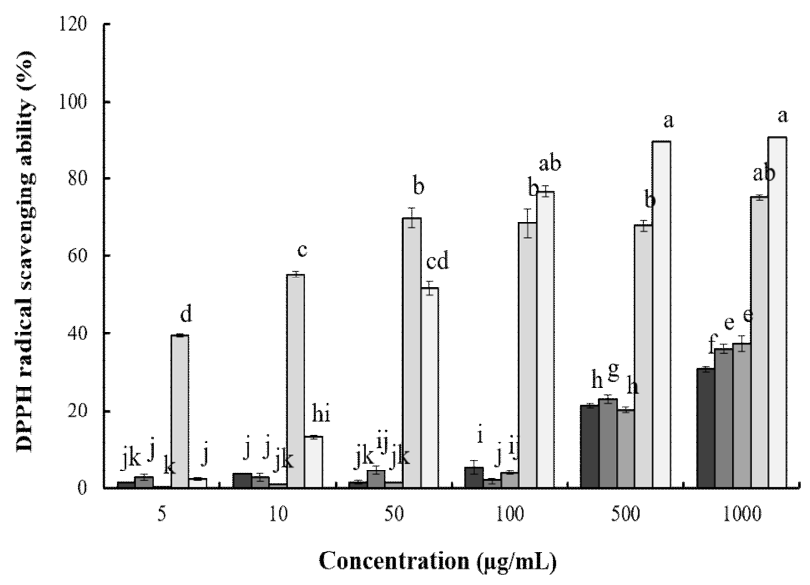

Fig. 3. Electron donating ability of hardy kiwifruit (Actinidia arguta) extracts.

HKW, hardy kiwifruit extracted with water; $\square$ HKE, hardy kiwifruit extracted with $70 \%$ ethanol; $\square$ HKA, hardy kiwifruit extracted with 70\% acetone; $\square$ EGCG, Epigallocatechin gallate; $\square$ BHA, Butylated hydroxyanisole.

Data are presented as mean \pm SD of three independent experiments. Values different small letters represent statistical differences at $p<0.05$.

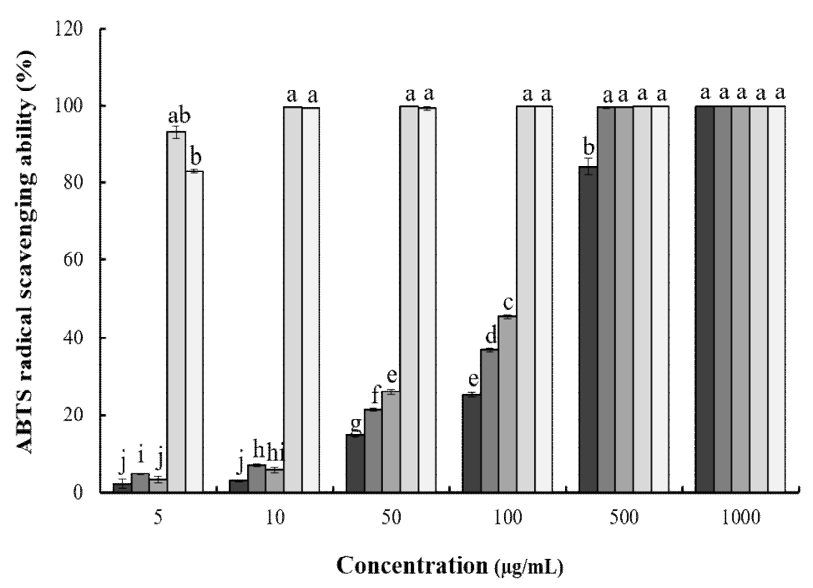

Fig. 4. $\mathrm{ABTS}^{+}$radical scavenging activity of hardy kiwifruit (Actinidia arguta) extracts.

$\square$ HKW, hardy kiwifruit extracted with water; $\square$ HKE, hardy kiwifruit extracted with $70 \%$ ethanol; $\square$ HKA, hardy kiwifruit extracted with $70 \%$ acetone; $\square$ EGCG, Epigallocatechin gallate; $\square$ BHA, Butylated hydroxyanisole.

Data are presented as mean \pm SD of three independent experiments. Values different small letters represent statistical differences at $\mathrm{p}<0.05$.

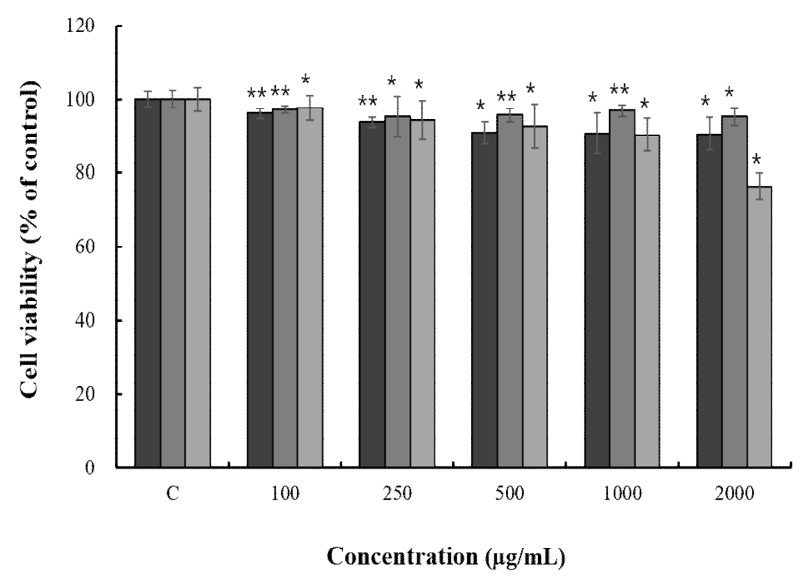

Fig. 5. Cell viability of RAW 264.7 macrophage cells treated with hardy kiwifruit (Actinidia arguta) extracts.

HKW, hardy kiwifruit extracted with water; HKE, hardy kiwifruit extracted with $70 \%$ ethanol; HKA, hardy kiwifruit extracted with $70 \%$ acetone.

$C$, control: untreated group other than DMEM

Raw 264.7 cells were treated with $5,10,25,50,100,200 \mu \mathrm{g} / \mathrm{mL}$ of HKW, HKE and HKA dissolved in DMEM media, and the cells were further incubated for 24 $h$. Data are presented as mean \pm SD of three independent experiments (significant as compared to control. ${ }^{*} \mathrm{p}<0.05$, ${ }^{\star *} \mathrm{p}<0.01$ ).

특히 식물함유 폴리페놀은 그 효능이 높은 것으로 알려져 있다. 또한, 효소활성뿐만 아니라, 세포 내 효소 단백질 발현 량을 조절하여 생리활성 반응을 조절한다(23-25). Tannic acid를 표준물질로 하여 표준곡선을 작성한 후, Fig. 1과 같이 추출 공정을 통하여 동결 건조된 용매 추출별 토종다 래의 폴리페놀 함량을 측정하여 Table 2 와 같이 나타내었 다. $\mathrm{HKW}$ 는 $15.54 \mathrm{mg} / \mathrm{g}, \mathrm{HKE}$ 는 $14.41 \mathrm{mg} / \mathrm{g}, \mathrm{HKA}$ 는 16.82 $\mathrm{mg} / \mathrm{g}$ 으로 $\mathrm{HKA}>\mathrm{HKW}>\mathrm{HKE}$ 순으로 폴리페놀 함량이 높은 것으로 나타났다.

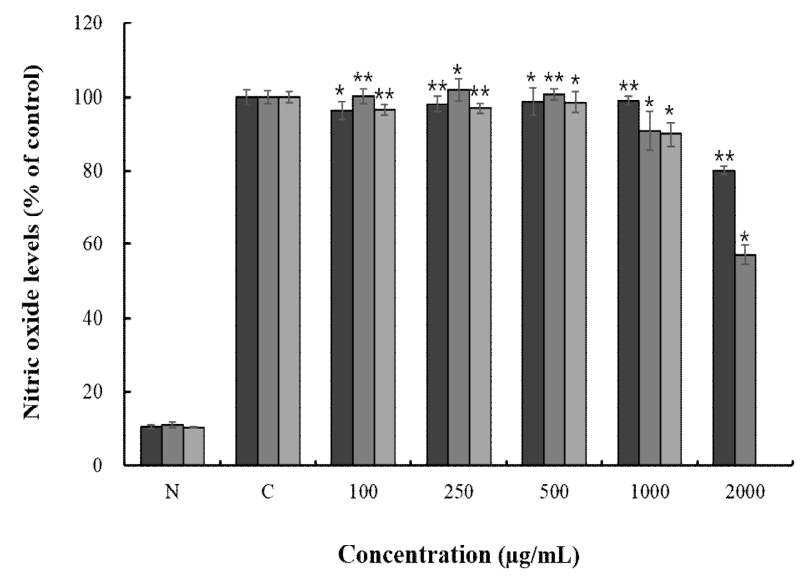

Fig. 6. Inhibition of nitric oxide by hardy kiwifruit (Actinidia arguta) extracts in RAW264.7 macrophage cells.

HKW, hardy kiwifruit extracted with water; HKE, hardy kiwifruit extracted with $70 \%$ ethanol; HKA, hardy kiwifruit extracted with $70 \%$ acetone $\mathrm{N}$, normal: LPS not induced group; C, control: LPS induced group. RAW 264.7 cells were treated with $5,10,25,50 \mu \mathrm{g} / \mathrm{mL}$ of HKW, HKE and HKA dissolved in DMEM media for $1 \mathrm{~h}$ prior to the addition of LPS $(1 \mu \mathrm{g} / \mathrm{mL})$, and the cells were further incubated for $24 \mathrm{~h}$ Data are presented as mean \pm SD of three independent experiments (significant as compared to control. ${ }^{*} \mathrm{p}<0.05$, ${ }^{* *} \mathrm{p}<0.01$ ). 

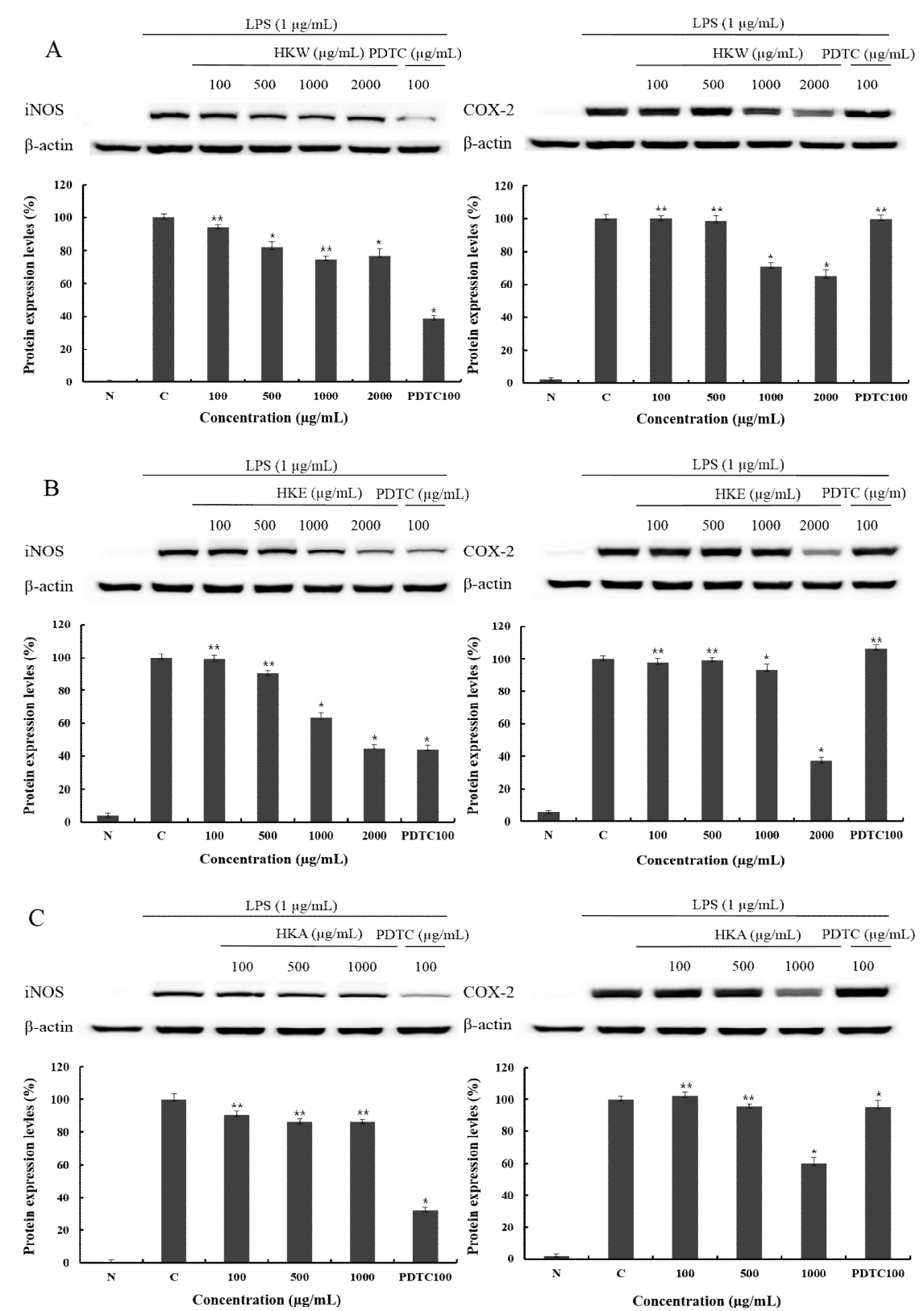

Fig. 7. Inhibition rate of i-NOS, COX-2 protein expressions in RAW 264.7 macrophage cells by hardy kiwifruit (Actinidia arguta) extracts. (A) $\mathrm{HKW}$, hardy kiwifruit extracted with water; (B) HKE, hardy kiwifruit extracted with $70 \%$ ethanol; (C) HKA, hardy kiwifruit extracted with $70 \%$ acetone. $\mathrm{N}$, normal: LPS not induced group; C, control: LPS induced group.

Data are presented as mean $\pm \mathrm{SD}$ of three independent experiments (significant as compared to control. ${ }^{*} \mathrm{p}<0.05$, ${ }^{*}{ }^{*} \mathrm{p}<0.01$ ).

\section{Hardy kiwifruit(Actinidia arguta) 의 전자공여능}

1,1-Diphenyl-2-picrylhydrazyl(DPPH)는 보라색을 띄며 비교적 안정한 자유라디칼을 갖는 화합물로서 $517 \mathrm{~nm}$ 파장 대에서 특징적인 광흡수를 나타낸다. 또한, polyphenol과 같은 hydroxyl기를 갖는 고분자 화합물 등에 의해 환원되어 탈색되므로 여러 소재에서 항산화물질을 확인하는데 많이 사용되고 있다(26). 토종다래의 전자공여능은 Fig. 3 와 같이 나타내었다. 최고 농도인 $1,000 \mathrm{\mu g} / \mathrm{mL}$ 에서 $\mathrm{HKW}$ 의 경우 $30.5 \%$ 로 나타났고 $\mathrm{HKE}$ 는 $36.1 \%$, HKA는 $37.4 \%$ 의 저해율
로 추출물간 큰 차이는 없는 것으로 확인할 수 있었다. 대조 군인 $\mathrm{EGCG}$ 와 $\mathrm{BHA}$ 는 $1,000 \mathrm{\mu g} / \mathrm{mL}$ 에서 각각 $75.1 \% 90.9 \%$ 의 전자공여능을 보였다.

\section{$\mathrm{ABTS}^{+}$radical scavenging activity assay}

$\mathrm{ABTS}^{+}$는 cation radical을 갖는 화합물로서 화합물 내 radical의 소거를 통한 색변화로 항산화 활성을 측정할 수 있는 실험방법이다. 실험 전 potassium persulfate와 ABTS를 미리 하루 정도 반응하여 청록색의 라디칼을 유도시킨다. 

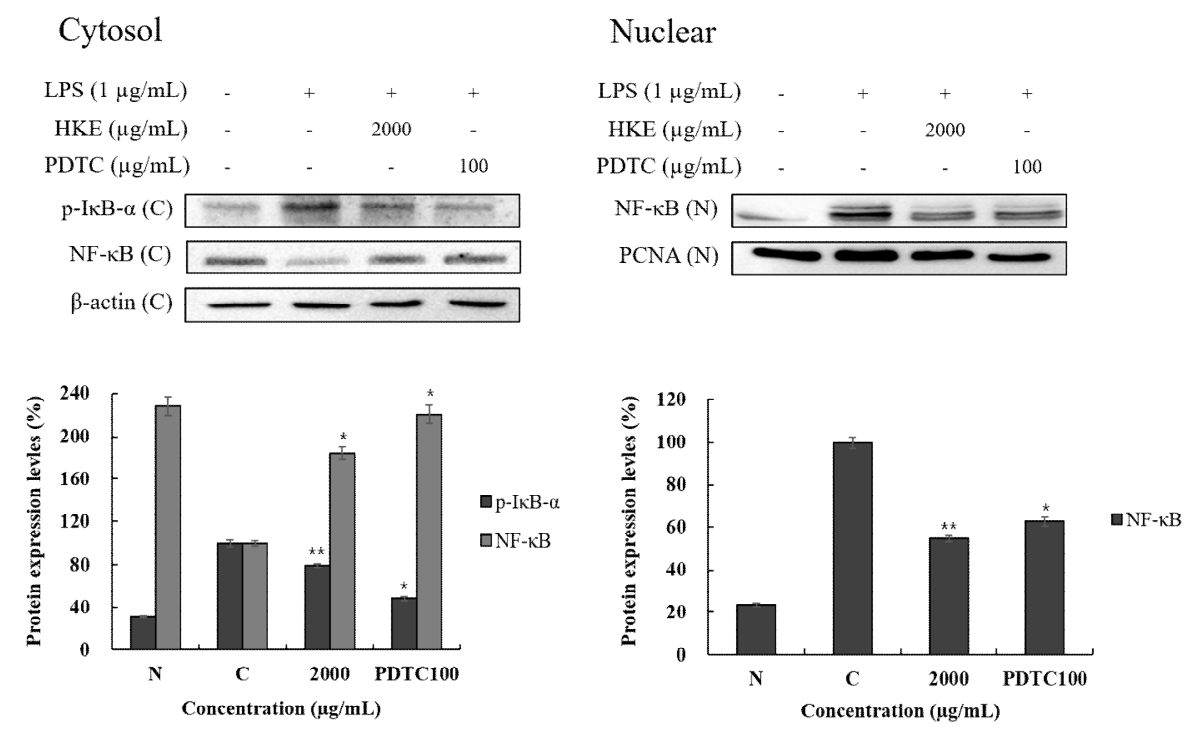

Fig. 8. Inhibition rate of p-IkB-a, NF-kB protein expressions in RAW 264.7 macrophage cells by hardy kiwifruit (Actinidia arguta) $70 \%$ ethanol extract.

N, normal: LPS not induced group; C, control: LPS induced group.

RAW 264.7 cells were treated with 2,000 $\mu \mathrm{g} / \mathrm{mL}$ of HKE dissolved in DMEM media for $1 \mathrm{~h}$ prior to the addtion of LPS $(1 \mu \mathrm{g} / \mathrm{mL})$, and the cells were futher incubated for $1 \mathrm{~h}$. Data are presented as mean $\pm \mathrm{SD}$ of three independent experiments (significant as compared to control. ${ }^{*} \mathrm{p}<0.05$, ${ }^{* *} \mathrm{p}<0.01$ ).

$\mathrm{ABTS}^{+}$은 환원되면 청록색에서 하늘색으로 변하며 hydrogen donating antioxidant와 chain breaking antioxidant 모두를 측정할 수 있는 특징을 갖는다. 토종다래의 $\mathrm{ABTS}^{+}$ radical scavenging activity는 Fig. 4에 나타내었다. 최고 농도 인 $1,000 \mu \mathrm{g} / \mathrm{mL}$ 에서 $\mathrm{HKW}$ 의 경우 $99.9 \%$ 로 나타났고 $\mathrm{HKE}$ 는 $99.8 \%, \mathrm{HKA}$ 는 $99.8 \%$ 의 저해율을 보여주었다. 이는 $1,000 \mu \mathrm{g} / \mathrm{mL}$ 의 $\mathrm{EGCG}$ 와 $\mathrm{BHA}$ 의 $99.83 \%, 99.8 \%$ 저해율와 유사한 수준의 측정치로 용매별 토종다래 추출물의 높은 $\mathrm{ABTS}^{+}$라디칼 소거능력을 확인할 수 있었다.

\section{Macrophage cell(RAW 264.7)의 세포 생존율 확인}

토종다래 추출물에 의한 macrophage cell의 세포 생존율 을 MTT assay를 통해 확인한 결과를 Fig. 5에 나타내었다. 추출 용매별, 농도별로 측정한 결과 $\mathrm{HKW}$ 와 $\mathrm{HWE}$ 는 농도 $2,000 \mu \mathrm{g} / \mathrm{mL}$ 까지 $90 \%$ 이상의 생존율을 보였고 $\mathrm{HKA}$ 는 $1,000 \mu \mathrm{g} / \mathrm{mL}$ 까지 $90 \%$ 이상의 생존율을 보였으며, 이후 진 행한 실험인 nitric oxide 측정 및 western blot, real-time PCR 은 세포생존율 구간을 참고하여 실험을 진행하였다.

\section{Nitric oxide 저해활성율}

Macrophage cell인 RAW 264.7에서 토종다래의 nitric oxide(NO)의 억제 정도를 측정하기 위해 용매별, 농도별로 샘플을 처리하여 $\mathrm{NO}$ 의 저해활성율을 측정한 결과 Fig. 6와 같이 나타내었다. 모든 용매에서 농도 의존적으로 감소하 는 결과를 보였고 $\mathrm{HKW}, \mathrm{HKE}$ 는 각 추출용매별 최고농도인 $2,000 \mu \mathrm{g} / \mathrm{mL}$ 에서 $20.0 \%, 42.8 \%$ 의 저해효과를 보였으며 $\mathrm{HKA}$ 는 최고농도인 $1,000 \mu \mathrm{g} / \mathrm{mL}$ 에서 $10.1 \%$ 로 $\mathrm{HKE}>$
$\mathrm{HKW}>\mathrm{HKA}$ 순으로 $\mathrm{NO}$ 의 저해활성을 보였다.

\section{Western blot을 통한 i-NOS 및 $\mathrm{COX}-2$ protein 발현 억제율}

토종다래 추출물에 의한 RAW 264.7 대식세포에서 염증 저해 기전을 보기 위해 i-NOS의 단백질 발현 및 COX-2의 발현을 측정한 결과 Fig. 7과 같이 나타내었다. $\mathrm{HKW}$ 는 $2,000 \mu \mathrm{g} / \mathrm{mL}$ 에서 i-NOS 발현 억제율이 $23.6 \%$ 로 측정되었 고, $\mathrm{COX}-2$ 의 발현 억제율은 $43.7 \%$ 로 측정되었다. $\mathrm{HKE}$ 는 $2,000 \mu \mathrm{g} / \mathrm{mL}$ 에서 i-NOS 발현 억제율이 $55.1 \%$ 로 측정되었 고, $\mathrm{COX}-2$ 의 발현 억제율은 $62.7 \%$ 로 측정되었다. $\mathrm{HKA}$ 는 $1,000 \mu \mathrm{g} / \mathrm{mL}$ 에서 i-NOS 발현 억제율이 $24.1 \%$ 로 측정되었 고, $\mathrm{COX}-2$ 의 발현 억제율은 $51.8 \%$ 로 측정되었다. 따라서 $\mathrm{HKE}>\mathrm{HKA}>\mathrm{HKW}$ 순으로 단백질 발현 억제율이 높게 나타났으며, 추출물 간에 비교적 큰 차이가 나타난 것으로 사료된다. 또한 $\mathrm{HKE}$ 는 대조군인 ammonium pyrrolidinedithiocarbamate(PDTC)에 비교하여도 높은 효능 을 보였으므로, 토종다래의 세포 내 NF- $\kappa \mathrm{B}$ 관련 단백질 및 염증성 사이토카인 $\mathrm{mRNA}$ 발현량 측정을 위해 $\mathrm{HKE}$ 로 처리하여 측정하였다.

Western blot을 통한 세포핵 및 세포질에서의 NF-kB protein 발현 확인

생체 내 대식세포는 Fig. 2와 같이 활성화될 때 LPS에 의한 세포막의 TLR4 수용체의 활성에 의한 $\mathrm{IkB}$ 의 인산화로 전사인자인 NF- $\mathrm{kB}$ 가 세포의 핵으로 유도되어 i-NOS, 
A

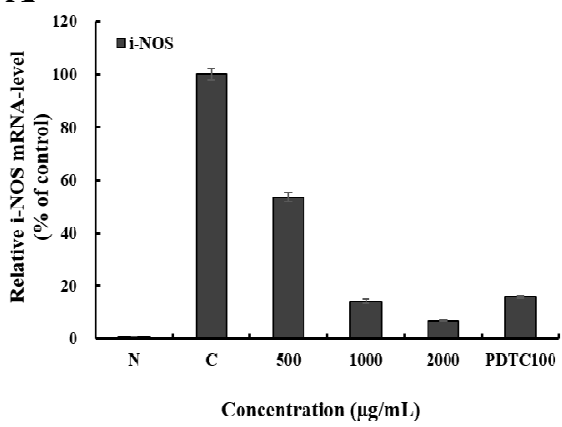

C

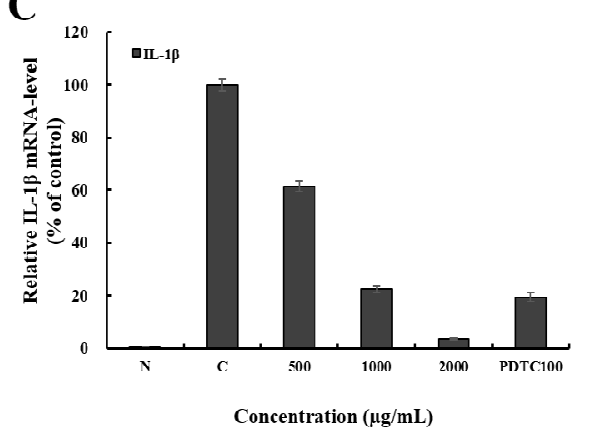

E

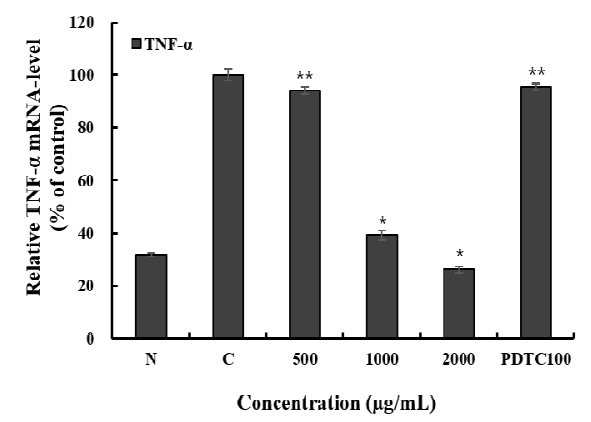

B

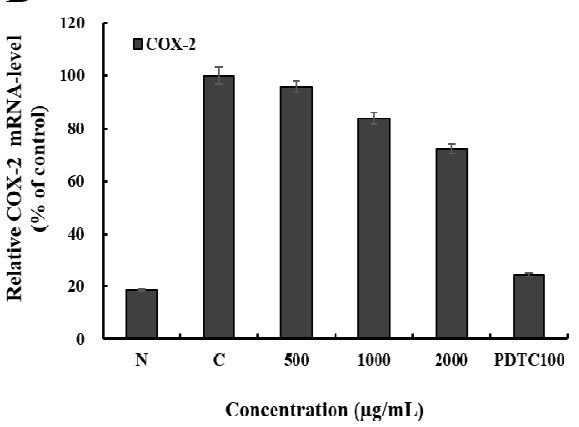

D

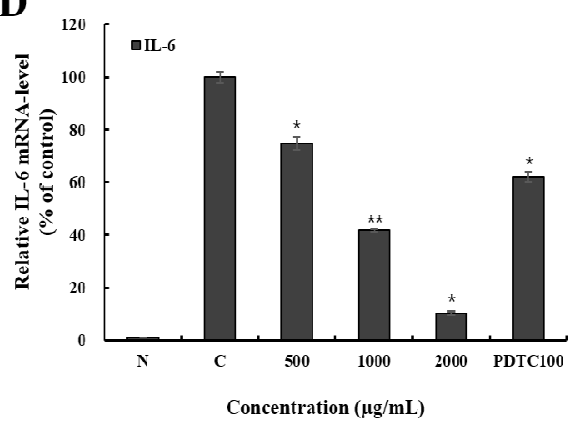

Fig. 9. Inhibition of inflammatory gene mRNA expressions in RAW 264.7 macrophage cells by hardy kiwifruit (Actinidia arguta) $70 \%$ ethanol extract.

(A), i-NOS; (B), COX-2; (C), IL-1ß; (D), IL-6; (E), TNF-a.

$\mathrm{N}$, normal: LPS not induced group; $\mathrm{C}$, control: LPS induced group.

Raw 264.7 cells were treated with 500, 1,000,2,000 $\mu \mathrm{g} / \mathrm{mL}$ of HKE dissolved in DMEM media for $1 \mathrm{~h}$ prior to the addition of LPS $(1 \mu \mathrm{g} / \mathrm{mL})$, and the cells were further incubated for $24 \mathrm{~h}$. Data are presented as mean $\pm \mathrm{SD}$ of three independent experiments (significant as compared to control. ${ }^{*} \mathrm{p}<0.05$, ${ }^{* *} \mathrm{p}<0.01$ ).

COX-2 등의 염증인자들을 생성하는 것으로 알려져 있 다. HKE의 NF-kB 경로의 확인을 위해서 세포를 nuclear와 cytosol로 분리하여 NF-kB관련 단백질 발현을 Fig. 8과 같이 나타내었다. $\operatorname{HKE}(2,000 \mu \mathrm{g} / \mathrm{mL})$ 는 cytosol에서 NF-kB의 양 은 $84.6 \%$ 증가 및 $\mathrm{p}-\mathrm{IkB}$ 의 발현양은 $20.6 \%$ 억제되었으며, nuclear에서 NF-kB의 양은 $45.4 \%$ 감소되었다. PDTC $(100$ $\mu \mathrm{g} / \mathrm{mL}$ )의 경우는 cytosol에서 NF-kB 의 양은 $121.0 \%$ 증가 및 $\mathrm{p}-\mathrm{I} \kappa \mathrm{B}$ 의 발현양은 $51.8 \%$ 억제되었으며, nuclear에서 NF$\kappa \mathrm{B}$ 의 양은 $37.4 \%$ 감소되었다. 따라서 $\mathrm{HKE}$ 는 NF- $\mathrm{kB}$ 전사 인자가 $\mathrm{IKB}$ 의 인산화 저해에 의하여 핵으로 유도되는 과정 을 억제하였음을 확인할 수 있었다.
Real-time PCR을 통한 다양한 mRNA 발현 억제 효과 RAW 264.7에서 HKE에 의한 i-NOS, COX-2, 및 IL-1 $\beta$, $\mathrm{IL}-6, \mathrm{TNF}-\mathrm{a}$ 의 mRNA 발현을 측정한 결과 Fig. 9와 같이 나타내었다. HKE는 i-NOS와 COX-2 mRNA 발현을 100 $\mathrm{\mu g} / \mathrm{mL}$ 에서는 각각 약 $93.2 \%, 27.9 \%$ 의 억제를 하였으며, 대조군인 PDTC는 $100 \mu \mathrm{g} / \mathrm{mL}$ 에서 i-NOS, COX-2 mRNA 발현을 각각 $84.1 \%, 75.5 \%$ 억제하였다. HKE는 PDTC 보다 COX-2 억제 효과는 약간 낮으나 i-NOS 억제 효과가 거의 근접함을 확인할 수 있었다. 또한 $\mathrm{HKE}$ 는 염증관련 cytokine 으로 $\mathrm{IL}-1 \beta, \mathrm{IL}-6$ 그리고 TNF-a mRNA 발현을 $100 \mu \mathrm{g} / \mathrm{mL}$ 에 서 각각 $96.4 \%, 89.4 \%, 73.9 \%$ 의 억제하였으며, 대조군인 
PDTC는 $100 \mu \mathrm{g} / \mathrm{mL}$ 에서 IL-1ß, IL-6 그리고 TNF-a mRNA 발현을 각각 $80.6 \%, 38.0 \%, 4.6 \%$ 을 억제하였다. $\mathrm{HKE}$ 는 PDTC와 비교할 때 IL-1 $1 \beta, \mathrm{IL}-6, \mathrm{TNF}-a$ 의 mRNA 발현 모두 높은 억제율을 보여 $\mathrm{HKE}$ 의 우수한 저해효과를 확인할 수 있었다.

최근 나고야 의정서로 인하여 자생 동식물 종의 연구가 필요한 실정이다. 토종다래는 식품소재로서의 역할 뿐만 아니라, 약품, 기능성화장품 등에서의 활용 가능성을 가지 고 있다. 토종다래 추출물은 전자공여능, $\mathrm{ABTS}^{+}$radical scavenging 활성 등의 항산화에 효능이 있는 것으로 나타났 으며, nitric oxide 저해활성, i-NOS 및 COX-2 발현 및 pro-inflammatory cytokine 류인 TNF-a, IL-1 1 , IL-6 그리고 NF-kB pathway의 억제 등 항염증 소재로서도 효능을 나타 내었다.

이러한 결과를 종합해 볼 때, 토종다래는 항산화, 항염증 뿐만 아니라 다른 다양한 분야에서도 연구해볼 만한 가치와 가능성을 가진다고 사료된다.

\section{요 약}

본 연구의 목적은 토종다래의 용매별 추출물에 따른 약 리활성에 대한 검증 및 효능 평가로서 토종다래의 항산화, 항염증에 대한 효과를 확인하였다. 염증 반응은 자극이 가 해지면 histamine, serotonin, prostaglandin과 같은 혈관 활성 물질에 의해 혈관 투과성이 증대되어 염증을 유발하고 cytokine, free radical, lysosomal enzyme 등 다양한 매개 인 자가 관여한다. 자극에 의한 macrophage cell의 염증반응은 tumor necrosis factor-a(TNF-a), interleukin-6(IL-6), interleukin$1 \beta(\mathrm{IL}-1 \beta)$ 와 같은 pro-inflammatory cytokine의 발현이 유도 되고, inducible nitric oxide synthase(i-NOS)와 cyclooxygenase-2 (COX-2)에 영향을 받는 유전자의 발현을 자극하게 되어 nitric oxide(NO) 등의 염증 인자가 생성된다. 이에 따라 토종다래 추출물의 항염증에 대한 연구를 위해 이에 영향을 주는 인자인 i-NOS, COX-2의 단백질 발현억제 작용을 확인 하였다. 그 결과, $\mathrm{HKE}>\mathrm{HKA}>\mathrm{HKW}$ 순서로 높은 효능을 확인 할 수 있었다. 가장 효과가 좋은 $\mathrm{HKE}$ 처리군에서 다양한 염증성 인자의 $\mathrm{mRNA}$ 발현량을 확인하였다. 측정

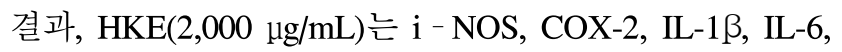
TNF-a mRNA 발현이 각각 $93.2 \%, 27.9 \%, 96.4 \%, 89.4 \%$, $73.9 \%$ 억제되는 효과를 확인할 수 있었다. 또한, $\mathrm{HKE}$ 의 nuclear factor kappa B(NF-kB) 단백질 발현에 농도의존적으 로 유의미한 결과를 확인하였으며, 이에 토종다래의 항염 증효과는 LPS에 의한 TLR4의 자극에서 NF-kB 경로의 완 화로 나타는 것임을 검증하였다.

결론적으로 토종다래는 $70 \%$ ethanol 추출물(HKE)의 항 염증 효과가 가장 높았으며, HKE는 대식세포에서 NF-kB
염증관련 경로의 억제로 세포 내 $\mathrm{mRNA}$ 및 단백질 수준에 서의 염증인자들의 생성을 저해하여 항염증 효과가 명백히 확인되었다.

향후 본 연구팀은 토종다래의 항염증과 관련된 유효성분 의 분리정제 및 구조분석을 진행할 예정이다.

\section{감사의 글}

본 연구는 중소기업벤처부 산하기관인 중소기업기술정 보진흥원의 도약기술개발사업(과제번호: C056417)의 지원 에 의해 수행되었으며 이에 감사드립니다.

\section{References}

1. Haddad JJ (2002) Antioxidnat and prooxidant mechanisms in the regulation of redox (y)-sensitive transcription factors. Cell signalling, 14, 879-897

2. Beckman KB, Ames BN (1998) The free radical theory of aging matures. Physiol Rev, 78, 547-581

3. Ding C, Cicuttini F, Li J, Jones G (2009) Targeting IL-6 in the treatment of inflammatory and autoimmune diseases. Expert Opin Invest Drugs, 18, 1457-1466

4. Higashisaka K, Fujimura M, Taira M, Yoshida T, Tsunoda S, Baba T, Yamaguchi $\mathrm{N}$, Nabeshi $\mathrm{H}$, Yoshikawa T, Nasu M, Yoshioka Y, Tsutsumi Y (2014) Asian dust particles induce macrophage inflammatory responses via mitogen-activated protein kinase activation and reactive oxygen species production. J Immunol Res, 2014, 1-9

5. Bekki K, Ito T, Yoshida Y, He C, Arashidani K, He M, Sun G, Zeng Y, Sone H, Kunugita N, Ichinose T (2016) PM2.5 collected in China causes inflammatory and oxidative stress responses in macrophages through the multiple pathways. Environ Toxicol Pharmacol, 45, 362-369

6. Rankin JA (2004) Biological mediators of acute inflammation. AACN Clin Issues, 15, 3-17

7. Guzik TJ, Korbut R, Adamek-Guzik T (2003) Nitric oxide and superoxide in inflammation and immune regulation. J Physiol Pharmacol, 54, 469-487

8. Goodwin JS, Ceuppens J (1983) Regulation of the immune response by prostaglandins. J Clin Immunol, 3, 295-315

9. Li X, Xu X (2011) TLR4-mediated activation of macrophages by the polysaccharide fraction from 
Polyporus umbellatus (pers.) Fries. J Ethnopharmacol, 135, 1-6

10. Tak PP, Firestein GS (2001) NF-kB: A key role in inflammatory diseases. J Clin Invest, 107, 7-11

11. Guha M, Mackman N (2001) LPS induction of gene expression in human monocyte. Cell Signalling, 13, 85-94

12. Matich AJ, Young H, Allen JM, Wang MY, Fielder S, McNeilage MA, MacRae EA (2003) Actinidia arguta: volatile compounds in fruit and flowers. Phytochemistry. 63, 285-301

13. Wojdylo A, Nowicka P, Oszmianski J, Golis T (2017) Phytochemical compounds and biological effects of Actinidia fruits. J Funct Foods, 30, 194-202

14. Jin DE, Park SK, Park CH, Seung TW, Choi SG, Heo HJ (2015) Nutritional components of Korean traditional actinidia (Actinidia arguta) sprout and in vitro antioxidant effect. Korean J Food Sci Technol, 47, 37-43

15. Ho SH, Park EJ, Choi JH, Eo HK, Hong ES, Kim SY, Kim SH (2009) Effect of PG102, a water-soluble extract from Actinidia aguta on canine atopic dermatitis. Korean J Pharmacogn, 40, 59-64

16. Hong ES, Kim MJ, Kwon EJ, Kim LH, Kim DH, Eo HK, Park EJ, Kim SY, Kim SH (2008) Subacute toxicological study of PG102, a water-soluble extract derived from Actinidia arguta, in SD rats. Korean J Vet Res, 48, 413-421

17. An X, Lee SG, Kang H, Heo HJ, Cho YS, Kim DO (2016) Antioxidant and anti-inflammatory effects of various cultivars of kiwi berry (Actinidia arguta) on lipopolysaccharide-stimulated raw 264.7 cells. J Microbiol Biotechnol, 26, 1367-1374
18. Folin O, Denis W (1912) On phosphotungasticphosphomolybdic compounds as color regents. J Biol Chem, 12, 239-249

19. Blois MS (1958) Antioxidant determinations by the use of a stable free radical. Nature, 181, 1199-1200

20. Re R, Pellegrini N, Proteggente A, Pannala A, Yang M, Rice-Evans C (1999) Antioxidant activity applying an improved ABTS radical cation decolorization assay. Free Radical Biol Med, 26, 1231-1237

21. Carmichael J, DeGraff WG, Gazdar AF, Minna JD, Mitchell JB (1987) Evaluation of a tetrazolium-based semiautomated colorimetric assay: Assessment of chemosensitivity testing. Cancer Res, 47, 936-942

22. Bartholomew B (1984) A rapid method for the assay of nitrate in urine using the nitrate reductase enzyme of Escherichia coli. Food Chem Toxicol, 22, 541-543

23. Duthie G, Crozier A (2000) Plant-derived phenolic antioxidants. Curr Opin Clin Nutr Metab Care, 3, 447-451

24. Ferreres F, Gomes D, Valentao P, Goncalves R, Pio R, Chagas EA, Seabra RM, Andrade PB (2009) Improved loquat (Eriobotrya japonica Lindl.) cultivars: variation of phenolics and antioxidative potential. Food Chem, 114, 1019-1027

25. Shahidi F, Janitha PK, Wanasundara PD (1992) Phenolic antioxidants. Crit Rev Food Sci Nutr, 32, 67-103

26. Aoshima H, Tsunoue H, Koda H, Kiso Y (2004) Aging of whiskey increases 1,1-diphenyl1-2-picrylhydrazyl radical scavenging activity. J Agric Food Chem, 52, 5240-5244 